\title{
REVIVAL, ENLIGHTENMENT, CIVIC HUMANISM, AND THE DEVELOPMENT OF DOGMA: SCOTLAND AND AMERICA, 1735-1843
}

\author{
Mark A. Noll
}

In 1846 one of America's most representative religious thinkers, Charles Grandison Finney, published the Lectures on Systematic Theology that he had earlier offered to students at Oberlin College. A central theme of those lectures was Finney's rejection of the dominant theology of previous generations, a rejection nowhere more explicit than in his comments on Jonathan Edwards. According to Finney, Edwards had erred particularly in describing the abilities of human beings before God. 'Men have been told,' wrote Finney, 'that they are as really unable to will as God directs, as they were to create themselves . . . Ridiculous! Edwards I revere; his blunders I deplore. I speak thus of this Treatise on the Will, because ... it abounds with unwarrantable assumptions, distinctions without a difference, and metaphysical subtleties ... It has bewildered the head, and greatly embarrassed the heart and the action of the church of God'.1

Less than three years before the publication of Finney's Lectures, Scotland's most influential clergyman of the period, Thomas Chalmers, expressed an entirely different opinion on the same subject: "There is no European Divine to whom I make such frequent appeals in my class rooms as I do to [Jonathan] Edwards. No book of human composition which I more strenuously recommend than his Treatise on the Will,-read by me forty-seven years ago, with a conviction that has never since faltered, and which has helped me more than any other uninspired book, to find my way through all that might

${ }^{1}$ C. Finney, Lectures on Systematic Theology (New York, George H. Doran 1876, orig. 1846) 333. On the predominance of theologies like Finney's in the antebellum United States, see T. L. Smith, Revioalism and Social Reform: American Protestantism on the Eve of the Civil War (Baltimore, Johns Hopkins University Press 1980, orig. 1957) 15-33. 
otherwise have proved baffling and transcendental and mysterious in the peculiarities of Calvinism'. ${ }^{2}$

The contrast between Finney and Chalmers on Edwards's Freedom of the Will illustrates nicely a larger contrast in Scottish and American ecclesiastical history from the 1730 s to the 1840 s. $^{3}$ During this period the Scottish and American churches passed through a similar set of circumstances. Each absorbed the impact of revival, each confronted a growing pluralism in religious allegiance, each faced the challenge of the Enlightenment, and each advanced along a path from aristocratic to democratic social order. At the same time, though they shared much, the Scottish and American churches did not share a common course of theological development. At the beginning of the period, both embraced a largely Calvinistic theology. By the end of the period the centre of American theology, as represented by Finney, had moved considerably beyond Calvinism, while the centre of theology in Scotland had become, if anything, more thoroughly Reformed than it was a century before.

The burden of this paper is to interpret comparatively the course of theological development in Scotland and America over this period. Its argument is that study of the relationship between formal religious thought and its social, political, and intellectual contexts shows why theology developed differently in the two regions during this period. ${ }^{4}$ The argument is not that this procedure provides the only, or even the best, explanation for the development of theological convictions, but merely that it offers one plausible interpretation.

In many respects-size, numbers and diversity of population-Scotland and America were quite different places in the middle of the eighteenth century. In theology, however,

${ }^{2}$ Chalmers to William B. Sprague, in Sprague, Annals of the American Pulpit (New York, Robert Carter and Brothers 1859) 1:334.

${ }^{3}$ On the congruence of Scottish and American events in this general period also with similar developments in the Netherlands, see J. H. S. Burleigh, A Church History of Scotland (London, OUP) 353; and D. Maclean, Aspects of Scottish Church History (Edinburgh, T .\& T. Clark 1927) 97-8.

4 In these terms, the paper is an effort to expand upon the promising essay of $D$. W. Howe, 'The Decline of Calvinism: An Approach to Its Study,' Comparative Studies in Society and History 14 (1972) 306-27, which traces the passing of Calvinism to the successes of capitalism. 
the two regions were strikingly similar. In both, a hereditary Calvinism provided the dominant theological perspective. In both, this 'people's Calvinism' nurtured a cherished view of a heroic Christian past. Both areas were also conscious that they upheld their religions as people on a periphery, colonists susceptible to the dominance of London and the imperialistic aspirations of the English. ${ }^{5}$ In fact, if a difference can be noted, it was that Scotland seemed to be moving away from its ancestral Calvinism more rapidly than America from its.

It says a good deal for the theological leanings of Scotland that in the years before the Cambuslang revival of 1742, the General Assembly had taken harsher steps against the activities of evangelical Calvinists than against the more systematic efforts of the rational party. The Assembly's harsh dealings with the supporters of Edward Fisher's Marrow led directly to the secession of Ralph and Ebenezer Erskine and their colleagues from the Kirk. On the other hand, its investigations of rationalistic theological professors John Simson and William Hamilton were leisurely and hindered at every point by the influential friends of these professors. The result by the 1740s was a situation in which, as one historian summarizes it, 'the Church's most acute thinkers, by challenging the dogmatism of a previous age, prompted by the attacks of the opponents of the Christian religion as well as stimulated by the new departures in philosophy and science, were ... helping to create a liberalising atmosphere in which the spirit of enlightenment could thrive. ${ }^{6}$

In America, by contrast, although ecclesiastical structures were more pluralistic, theological convictions were

${ }^{5}$ See J. Clive and B. Bailyn, 'England's Cultural Provinces: Scotland and America', William and Mary Quarterly, 3rd. ser., 11 (1954) 179-9.

${ }^{6} \mathrm{~J}$. K. Cameron, 'Theological Controversy: A Factor in the Origins of the Scottish Enlightenment', in R. H. Campbell and A. S. Skinner (edd.), The Origin and Nature of the Scottish Enlightenment (Edinburgh, John Donald 1982) 128. On the general situation at this time, see A. L. Drummond and James Bulloch, The Scottish Church 1688-1843: The Age of the Moderates (Edinburgh, Saint Andrew 1973) 31-48; S. Mechie 'The Theological Climate in Early Eighteenth Century Scotland', in D. Shaw (ed.) Reformation and Reoolution (Edinburgh, Saint Andrew 1967) 258-72; H. Sefton "Neu Lights and Preachers Legall": Some Observations on the Beginnings of Moderatism in the Church of Scotland', in Norman MacDougall (ed.), Church, Politics and Society: Scotland 1408-1929 (Edinburgh, John Donald 1983) 186-96. 
more thoroughly Reformed. The mainstream theology of the Americal colonies in the 1720 s and 1730 s testified to the weight of Puritan influence. In particular, the heart of formal religious thought remained a massive commitment to the centrality of God's grace for the salvation of individuals, their incorporation into the church, and their orientation to society. ${ }^{7}$

It is a testimony to the continuing power of Calvinism in America that the most important religious events of the period, the great colonial revivals, were promoted by men-Theodore Frelinghuysen, Gilbert Tenennt, and especially George Whitefield-who affirmed this theology; and that the revivals became the occasion for the century's greatest theologian, Jonathan Edwards, to restate the precepts of Calvinism with rigorous force. To be sure, some colonists by $\mathbf{1 7 4 0}$ were questioning Calvinistic certainties, and Protestant theology had certainly moved in the direction of activism, moralism, and, to some extent, individualism during its first American century. At the same time, covenantal Calvinism still defined the mainstream.

From that fairly secure Calvinistic base, however, the centre of gravity of American theology would shift dramatically over the next century. In Scotland, by contrast, a relatively less secure Calvinism became more sharply defined over the same period. The question now is why the development of doctrine took place in contrasting ways in the two areas.

In America the evolution beyond Calvinism began not with developments in theology, but in the life of the church, and in the relationship of church to society. The most important of the ecclesiastical developments was the Great Awakening. The key event in the church's relation to society was the alliance between Puritan theology and the radical Whig tradition of civic humanism. The two developments, moreover, were intimately related. The Great Awakening was massively important for both churches and American society. For theology, its greatest impact was indirect, and resulted from the role of the Awakening in bringing disarray to the previously integrated notions of covenant, especially in New England.

7For an overview, see S. E. Ahlstrom, 'Theology in America: A Historical Survey', in J.W. Smith and A.L. Jamison (edd.), The Shaping of American Religion (Princeton, Princeton University Press 1961) 236-51. 
From the beginnings of New England, a theology of integrated covenants had provided a foundation for individual religion, church structure, and social order. ${ }^{8}$ The effect of the Great Awakening was to disrupt the integrating power of the covenant. In its wake the revival left several distinct ecclesiastical parties. In New England especially, these parties were separated by social allegiance as well as theological persuasion. Each, in fact, appropriated a different aspect of the covenantal tradition. ${ }^{9}$

The covenantal language that had provided a theoretical basis for Puritan society in early America no longer held together. The mainstream theology as such was not fragmented in the wake of the revival. Rather, the language that had bound together religion and the community, church and society, was now in ruins. The covenant had become all things to all men, and so nothing to them all.

The Awakening did not bring theological innovation, at least in a strictly dogmatic sense. In fact, as the occasion for the most affecting (with Whitefield) and the most brilliant (with Edwards) statement of Calvinism in American history, it was just the reverse. Yet in ideological terms the consequences of this theologically conservative movement were curious. The modes of its propagation brought it closer to the humanist assumptions of the 'real whig' political thinkers. It was in fact the essentially conservative thrust of the revival (to preserve the reality of individual salvation and the purity of the church) that detatched the social sense of covenant from its organic connections with person and church. It was then precisely the loss of an indigenously theological definition of society that allowed religious leaders to endorse as from God first the republicanism of civic humanism and then the individualism of

\footnotetext{
${ }^{8}$ See P. Y. De Jong, The Covenant Idea in New England Theology (Grand Rapids, Eerdmans 1945); P. Miller, The New England Mind: The Seventeenth Century (New York, Macmillan 1939) 365-491; and for English background, M. McGiffert, 'Grace and Works: The Rise and Division of Covenant Theology in Elizabethan Puritanism', HTR 75 (1982) 463-502.

${ }^{9}$ For overviews, see E. Scott Gaustad, The Great Awakening in New England (New York, Harper and Brothers 1957); and C. C. Goen, Revioalism and Separatism in New England, 1740-1800 (New Haven, Yale University Press 1962).
} 
laissez faire liberalism, two ideologies that would exert anything but a conservative influence on theology itself.

The French and Indian War became the occasion for the first full rehearsal of a distinctly Christian republicanism, as religious leaders, frightened by the menace of France and mesmerized by the evils of Rome, linked together liberty, property, and true Christianity as the colonies' bulwarks against slavery, corruption, and the Whore of Babylon. ${ }^{10}$ But the final stage in the creation of pietistic, covenantal civic humanism took place as tensions grew between the colonies and the mother country after 1763. During the crisis of independence, Americans of many sorts-clerical and lay, representing all regions of the country-made the language of Christian republicanism their own. ${ }^{11}$

And what of formal theology in the half-century after 1735 when so many Calvinists were busy linking central theological themes to key affirmations of civic humanism? To all appearances, there had been only slight changes. The apparent stability of the mainstream theology in 1789 was, however, deceptive. Once yoked with political ideology and enlisted fully as a servant of the national purpose, American theology was destined to reflect changes in the country's political thought and to be shaped by efforts at creating the new American civilization. In the early years of the republic, political ideology was in fact evolving from civic humanism-with ideals of disinterested public virtue and freedom defined as liberation from tyranny-toward political liberalism-with ideals of individualized private virtue and freedom defined as self-determination. In addition, fresh intellectual resources were being called into service for the effort to stabilize the new nation and subdue the frontier, including an increasing reliance

\footnotetext{
${ }^{10}$ See N. O. Hatch, 'The Origins of Civil Millennialism in America: New England Clergymen, War with France, and the Revolution', William and Mary Quarterly 3rd ser. 31 (1974) 407-30.

${ }^{11}$ See R. Bloch, Visionary Republic: Millennial Themes in American Thought, 1756-1800 (New York, CUP 1984); N. O. Hatch, The Sacred Cause of Liberty: Republican Thought and the Millennium in Revolutionary New England (New Haven, Yale University Press, 1977); J. F. Berens, Providence and Patriotism in Early America, 1640-1815 (Charlottesville, University Press of Virginia 1978); and M. A. Noll, Christians in the American Revolution (Grand Rapids, Eerdmans 1977).
} 
on the methodology of Newtonian scienticism and the reasoning of Scottish moral philosophy. Each of these national developments became important for American theology precisely because in the half-century between the Great Awakening and the Constitution America's religious leaders had identified themselves so thoroughly with the ebb and flow of American civilization.

The liberal ideology that became increasingly important in early America constituted, as Gordon Wood has put it, 'the self-interested pursuit of happiness' pointing to an emerging 'world of business, money-making, and the open promotion of interests'. ${ }^{12}$ In theology the liberal influence had at least something to do with a series of delicate manoeuvres through which the students of Jonathan Edwards modified gently earlier Calvinistic conceptions along lines suggested by current political concerns. Thus, to Joseph Bellamy, the work of Christ became not the placation of divine wrath (as had been traditional), but the restoration of moral order in the universe. ${ }^{13}$ For Samuel Hopkins, human sinfulness was the result only of the sins of individuals. Sinfulness, Hopkins was also eager to point out, did not conflict with God's kindly designs for the world, but actually increased the quality and quantity of human happiness by triggering the divine plan of redemption. ${ }^{14}$

Bellamy and Hopkins had not repudiated Calvinism. They continued to insist that people contributed nothing of their own to salvation. Yet even by the 1780 s the impact of liberal ideology was being felt. Bellamy and Hopkins had seen their mentor employ modern conceptions-Locke's sensationalism and Hutcheson's moral philosophy - to restate the traditional faith, but their own efforts to the same end-using this time the imperatives of human happiness and individual rights-were not as successful. The difference was that Edwards tried to use the new language in describing the old

${ }^{12}$ G. S. Wood, 'Ideology and the Origins of Liberal America', William and Mary Quarterly 3rd ser. 44 (1987) 635.

${ }^{13}$ For a good discussion of Bellamy's theology, see G. P. Anderson, Joseph Bellamy (1719-1790): The Man and His Work (Ph.D. diss., Boston University 1971).

${ }^{14}$ Solid commentary can be found in J. A. Conforti, Samuel Hopkins and the New Divinity Movement (Grand Rapids, Eerdmans 1981). 
dogma, while Bellamy and Hopkins had begun the process of re-defining the old dogma in line with the new language.

Newtonian scientism and Scottish moral philosophy also became influential conceptual languages in the $1780 \mathrm{~s}$, probably because they represented means of asserting public authority that did not depend upon the sanction of tradition or the habits of deference. By the late eighteenth century, Americans had sworn off both tradition and deference as means of ordering society. To take their place emerged 'philosophical' proof-meaning procedures of both physical and mental sciences supposedly accessible to all people. Neither mathematical demonstration nor the moral philosophy of Common Sense required the imprimatur of tradition. Rather, both strategies were widely held to convey a selfauthenticating authority. In theology, the second half of the eighteenth century witnessed a corresponding fascination with demonstration through science and the Scottish philosophy.

The intellectual history of the United States in the early national period is complex, especially for the connections between religion and public thought. ${ }^{15}$ Nonetheless, it now seems clear that between the ratification of the Constitution and the election of William Henry Harrison in 1840, the assumptions of the nation's public philosophy evolved, or completed their evolution, from a basic republicanism to a basic, if not exclusive, liberalism. The central context for this ideological evolution was the pressing circumstances of the new nation. Americans, first, faced the need to establish a discourse of authority in a society that had repudiated the traditional warrants for social ordering-deference to hierarchy, station, and history. Second, they confronted the challenge of civilizing the wilderness. In the first fifty years of the new nation. both the public philosophy and the mainstream theology were strained very nearly to the breaking point in the effort to meet these needs.

Throughout the period, roughly the same assumptions were at work in the political thought and the mainstream

${ }^{15}$ For necessary cautions about trying to read intellectual history from social conditions, see B. Kuklick, Churchmen and Philosophers From Jonathan Edwards to John Dewey (New Haven, Yale University Press 1985) 301-2. 
theology. In the public sphere, the language of liberalismemphasizing the freedom of individuals from hierarchical restraint and the formation of community upon the unfettered choices of free individuals joined by contract-became increasingly the language of politics and the economy. Liberalism also seems to have been used in propounding rationales for the salient characteristics of the period's religious life, of revival (where conversion was defined as an unmediated choice made by individuals), voluntary organization (where individuals joined together of their free will to move others toward the good), and the triumph of the believer's church (defined as the sum of its members, whose own choices brought it into existence). ${ }^{16}$ If the language of popular sovereignty, of the people, became the unquestioned argot of Jacksonian America, it was no less so for popular theology. The denominations that grew rapidly in the early republic-Methodists, Baptists, Disciples, Mormons, Millerite-all spoke the language of the people more distinctly that did the largest denominations from the colonial era, Congregationalists, Episcopalians, and Presbyterians. ${ }^{17}$ If in politics the Scottish Moral Philosophy provided a faculty psychology from which to draw analogies for the body politic and a moral sense intuition upon which to ground formal political theory, no less in religious thought did faculty psychology provide the starting point for theological anthropology and its moral sense intuitionism the foundation for soteriology. ${ }^{18}$ If a Newtonian scienticism running into

${ }^{16}$ I know of no study making these points directly. My conclusions rest on an incomplete reading of the immense current literature on the place of republicanism and liberalism in the early American nation. For summaries, see L. Banning, 'Jeffersonian Ideology Revisited: Liberal and Classical Ideas in the New American Republic', and J. Appleby, 'Republicanism in Old and New Contexts', William and Mary Quarterly 3rd ser. 43 (1986) 3-19, 20-34; and the special issue, J. Appleby (ed.), 'Republicanism in the History and Historiography of the United States', American Quarterly 37 (1985) 461-598.

${ }^{17}$ See especially N. O. Hatch, The Democratization of American Christianity (New Haven, Yale University Press, forthcoming).

${ }^{18}$ See D. W. Howe, 'The Political Psychology of The Federalist', William and Mary Quarterly 3rd ser. 44 (1987) 485-509; D. H. Meyer, The Instructed Conscience: The Shaping of the American National Ethic (Philadelphia, University of Pennsylvania Press 1972); and D. L. Weddle, The Law as Gospel: Revioal and Reform in the Theology of Charles G. Finney (Metuchen, N.J., Scarecrow) ch. 6 'The Plan of Salvation'. 
Baconianism offered the public a convincing model of inductive certainty, a similar scienticism infused the rage for natural theology among the elite and for biblical numerology among the population at large. ${ }^{19}$

In other words, America's religious leaders in the early national period were busy adjusting the mainstream theology in order to meet the spiritual needs of the new nation, needs that were themselves defined in considerable part by the conceptual structure of the new nation's public philosophy.

Many important qualifications must be neglected at this point in order to state the central reality of the period. If the most salient characteristic of American ideology in the 1730s was the bond between a pious Puritanism and classical republicanism, the most salient characteristic of American ideology in the 1840s was the bond between democratic evangelicalism and democratic liberalism. A clear indication of that bond is the shift in theological conceptions between the mid-eighteenth and the mid-nineteenth centuries, a shift displaying a remarkable resemblance to the shifts of meaning in the public philosophy. It oversimplifies matters somewhat to cite Edwards as a benchmark from the 1730s against which to compare the theologies of Finney and of Yale's Nathaniel William Taylor, the era's most distinguished theologian, a century later. Yet the contrast is still instructive.

The most obvious change in the century under consideration concerned notions of freedom. To republicans, liberty meant 'the right of the people to share in the government'. In liberal America it had become 'unrestrained competition and equality, an absence of built-in handicap' ${ }^{20}$ The parallel development in theology was just as abrupt. In Edward's

${ }^{19}$ See W. Smith, 'William Paley's Theological Utilitarianism in America', William and Mary Quarterly 3rd ser. 11 (1954) 402-24; T. D. Bozemn, Protestants in an Age of Science: The Baconian Ideal and Antebellum American Religious Thought (Chapel Hill, University of North Carolina Press 1977); and on popular biblical numerology, R. L. Numbers and J. M. Butler (edd.), The Disappointed: Millerism and Millenarianism in the Nineteenth Century (Bloomington, Indiana University Press 1987).

${ }^{20}$ G. S. Wood, The Creation of the American Republic, 1776-1787 (Chapel Hill, University of North Carolina Press 1969) 609; I. Kramnick, 'Religion and Radicalism: English Political Theory in the Age of Revolution', Political Theory 5 (1977) 514. 
Freedom of Will, liberty meant 'power, opportunity, or advantage, that anyone has, to do as he pleases. Or in other words, his being free from hindrance or impediment in the way of doing, or conducting in any respect, as he wills' ${ }^{21}$ For Taylor freedom meant 'power to the contrary' in all moral choices; a person was 'a Free Agent without the Aids of Divine Grace'. Finney was even more direct: "The moral government of God everywhere assumes and implies the liberty of the human will, and the natural ability to obey God. Every command, every threatening, every expostulation and denunciation in the Bible implies and assumes this . . . The human mind necessarily assumes the freedom of the human will as a first truth' ${ }^{22}$ In 1740 'freedom' was something about which to reason, a quality of human life to be considered in relation to other aspects of existence, and a positive value that nevertheless needed to be fenced in by other weightier considerations. By 1840 it had become axiomatic, the fundamental defining trait of humanity, and a value than which nothing was greater.

America's Christian theologians in 1840 wanted very much to see the population converted, to make their society godly, and to show citizens of the world how their unique blend of Protestant evangelicalism and liberal democracy could open the way to the millennium. To reach these goals it was necessary to speak persuasively, to witness with power. For their appeal, the theologians needed a language that could be understood, a language that could persuade their fellow Americans. Because of a long tradition of inter-conceptual borrowing between the language of theology and the language of public philosophy, it had become second nature to make those appeals in the language of the then dominant public philosophy. But since ideologies embedded in cultures-words in flesh-have a historical logic of their own, there is scant surprise that as Christian theologians learned the language of political and economic liberalism, political and economic liberalism transformed the language of Christian theology.

${ }^{21}$ J. Edwards, Freedom of the Will (ed. P. Ramsay; New Haven, Yale University Press 1957, orig. 1754) 163.

${ }^{22}$ Taylor quoted in G. M. Marsden, The Eoangelical Mind and the New School Presbyterian Experience (New Haven, Yale University Press 1970) 49; Finney, Systematic Theology 335. 
As we turn now to the theological history of Scotland, it is important to make a necessary distinction. Two general processes were at work in America with respect to the development of doctrine. The first was formal and concerned the church's stance in its culture. It was a matter of ordering relationships, a question of importing and exporting intellectual assumption. When American religious thinkers abandoned the Puritans' traditional integration of covenants without establishing an alternative theological conception of social order, when they committed their faith to the cause of national independence, when they assigned to the philosophy of Common Sense the task of securing Christian faith in the new democratic setting, they reduced the control that they themselves exercised over their intellectual future. By ceding institutions, ideas, and formal agents of social ordering to processes of nature and the simple flow of events, they preserved their place in the wider society, but they also, at least in part, relinquished control over theology.

The second process was substantial and concerned the actual shape of theology. American theology was never the direct product of social theories, political ideologies, or the conventions of moral philosophy, but always the result of individuals and groups studying the Scriptures, reflecting on their own religious experience, and debating received traditions of Christian thought.At the same time, the formal process bore on this substantial process as developments in the broader culture shaped and delimited the range of concepts available for the church's theological task. Thus, we need to regard the theology of Finney as a product of his own religious experience, his own wrestling with the Bible, and his own involvement with other believers. But it was also a product, less directly, of his culture's more amorphous conventions concerning what was more generally ethical, just, fair, or logically persuasive. Such conventions for Finney were in some important respects different than for Edwards a century before precisely because of the nature of the church's involvement in its society's political, intellectual, and cultural life during the intervening time.

The general point to be made from the American experience, therefore, is that the history of theology involves two matters-purposeful theological construction and the 
conceptual environment in which that construction takes place. Furthermore, a church will have greater control over its doctrinal life-that is, the development of dogma will be more strictly related to the internal religious life of the church-to the extent that the church plays an active role in shaping the cultural assumptions of its environment. By contrast, the cultural assumptions of the environment will play a greater role in the development of dogma as the church cedes to that environment the determination of conceptual elements integral to the doing of theology. ${ }^{23}$

The history of doctrine in Scotland during the century from the Cambuslang revival of 1742 to the Disruption of 1843 is quite different than the history of doctrine in America during the same period. With their American contemporaries, Scottish churchmen also accommodated themselves to new forms of piety, especially revivalism. They also worked in an intellectual milieu defined by the tenets of Common Sense moral philosophy, Scotland's own contribution to the domestication of the Enlightenment. And they too faced a political situation defined by the language of classical civic humanism. In the face of these challenges, however, Scottish religious thinkers did not pursue the same course of action that Americans did. As a consequence, they enjoyed a different framework within which to do theology. Because of that difference, the contributions of individuals and events meant something different to the development of doctrine in Scotland than they did in America at the same time.

To put matters negatively first: in Scotland, revival reinforced the organic strength of the covenant rather than undermining it. In Scotland, the Christian version of the

${ }^{23}$ Since the interchange between church and society is continuous, the question always concern degrees of importation and exportation, or the balance of intellectual trade. In times of Christian expansion, the balance tips decisively in the direction of export, as indicated, for instance, by these comments from Peter Brown on the early church: 'Now it cannot be stressed often enough that the rise of Christianity in the third and fourth centuries was not merely the spread of certain doctrines in a society that already possessed its own principles of organization ... .; it was an effort of, often, rootless men to create a society in miniature, a "people of God"; its appeal lay in its exceptional degree of cohesion', Religion and Society in the Age of St. Augustine (New York, Harper and Row 1972) 136. 
Enlightenment functioned as a supplement to tradition and history rather than as a replacement for tradition and history. In Scotland, civic humanism did not lead on to popular sovereignty or political liberalism, but was enlisted on the side of hierarchy and deference. The result was that although Scottish church life felt the impact of revival, the Enlightenment, and civic humanism, these influences did not reduce the comprehensive intellectual vision of theologians as they had in America. Put positively, since Scottish Christians maintained the struggle comprehensively to control institutions and ideas, Scottish theology was left more nearly free to follow internal impulses, and from the 1770 s and 1780 s the most important of such impulses were Calvinistic.

In the first instance, revivalism was never as pervasive in Scotland as in America, nor did revivalism shape religious culture as thoroughly as in America. A comparison between Cambuslang and the First Great Awakening reveals important differences. ${ }^{24}$ Both featured the ministry of Whitefield, both witnessed a dramatic surge of conversions, both were fuelled by significant lay involvement, and both were attended by crowds of unprecedented size. The critical difference, however, was that the Scottish revivals acted as agents of communal cohesion instead of fragmentation. The Scottish revivals worked to solidify and evangelize the established church rather than to split it apart. The end result of New England's Great Awakening was a four-fold division in the established church. In Scotland, the revivals associated with Cambuslang led to a strengthened established church.

It is of the greatest importance-socially, theologically, culturally - that the focus of revival in New England was the preached word of an itinerant outsider whereas in Scotland it was the celebration of communion under the general

${ }^{24}$ For Cambuslang, I have depended on A. Fawcett, The Cambuslang Revioal: The Scottish Evangelical Revival of the Eighteenth Century, (London, Banner of Truth 1971); T. C. Smout, 'Born Again at Cambuslang: New Evidence on Popular Religion and Literacy in Eighteenth Century Scotland', Past and Present 97 (182) 114-27; and N. Landsman, 'Evangelists and Their Hearers: Popular Interpretations of Revivalist Preaching in Eighteenth-Century Scotland', Journal of British Studies, forthcoming. 
oversight of the parish minister. ${ }^{25}$ Moreover, the Scottish revivals did not lead to socially disruptive promotion of the 'pure church', as they did for Edwards, but rather to the evangelical strengthening of an establishment that maintained its comprehensive aspirations for Scottish society.

The situation for the Enlightenment was similar to the situation for revival. A process of accommodation that in America led to the decline of Calvinism did not have that result in Scotland. Religious thinkers in both venues admired Edwards for having put categories of the Enlighten-ment to work for Calvinism. ${ }^{26}$ In both regions a moral philosophy of Common Sense, developed first for ethics by Francis Hutcheson and then for general epistemological purposes against David Hume by Thomas Reid, contributed extensively to the shape of theology. ${ }^{27}$ In addition, theologians in both countries linked an exalted opinion of Newtonian scientific method to their use of the Scottish moral philosophy. In both places, that is, the tenets of this philosophy were widely accepted: that it was impossible not to presuppose the existence of an external world and normal connections of cause and effect, and that moral intuitions could be treated as axioms for a comprehensive ethics applicable in all situations. ${ }^{28}$ Yet despite these real similarities in the use of Scottish moral philosophy, the results for theology were quite different.

Environment, moreover, seems to be the key reason for the difference. In Scotland, evangelicals like John Wither-

${ }^{25}$ On how forms of revival affect the substance of religion more generally, see H. S. Stout, The New England Soul: Preaching and Religious Culture in Colonial New England (New York, Oxford University Press 1986), §IV, 'Delivery, 17311763'; and Stout, 'Puritanism Considered as a Profane Movement', Christian Scholar's Review 10 (1980) 3-19.

${ }^{26}$ See D. Bebbington's chapter on the eighteenth century in his forthcoming book on the evangelical tradition in Great Britain for what Edward's appropriation of the Enlightenment meant in Scotland.

27For a philosopher's introduction, see S. A. Grave, The Scottish Philosophy of Common Sense (Oxford, Clarendon 1960); and for a still useful summary paying more attention to theology, J. McCosh, The Scottish Philosophy: Biographical, Expository, Critical, from Hutcheson to Hamilton (New York, Robert Carter and Brothers 1875).

${ }^{28}$ An effort to distinguish ethical from epistemological aspects of Scottish Common Sense philosophy is found in M. A. Noll, 'Common Sense Traditions and American Evangelical Thought' American Quarterly , 37 (1985) 220-5. 
spoon, John Erskine, Charles Nesbit, and Thomas Chalmers-as well as William Robertson's circle of Moderates and their successors like George Hill of St. Andrews-used Common Sense moral philosophy primarily to repudiate the scepticism of David Hume, and in order to reconcile religious faith and the deliverances of reason. Unlike their counterparts in America, Scottish theologians did not look to Common Sense moral philosophy as the principal means of creating public order in the face of frontier chaos nor to erect an apologetic for Christianity in the face of a barbaric rejection of tradition. In Scotland, that is, the Common Sense philosophy worked its greatest effect in the domain of formal academic thought. The Scots looked much more to the Westminster Confession than to the Argument from Design in order to sustain orthodox theology. At times of crisis like the French Revolution and the threat of Napoleon, they tended to rely much more on the institutions of the established church and the society as a whole for shoring up public morality and social order than on 'the science of politics'.

A biographical focus illustrates the divergent course of the Enlightenment in Scotland and America. John Witherspoon was a leading minister in the Kirk's Popular or Evangelical Party from the mid-1740s to 1768 when he migrated to America to become the president of Princeton College. In Scotland, Witherspoon had written articles affirming the reliability of the senses, a theme prominent among more famous proponents of the Scottish Philosophy. But he was best known for his satiric attacks on the Moderates, including their ethical mentor Francis Hutcheson. As a Scottish evangelical Witherspoon employed the Common Sense philosophy of his Moderate contemporaries for narrow philosophical purposes. But he denounced the Moderate effort to give polite philosophy a dominant role in shaping the theology and institutions of the church or in governing the social order.

In America, Witherspoon's convictions did not change. But with the absence of a settled social structure, in a situation where Presbyterians had to exert great efforts at bringing more of the vast unchurched population under their influence, and at a time when radical social ideas seemed to threaten both social order and the future of religion, Witherspoon's philosophical 
convictions moved from the periphery to the centre. ${ }^{29}$ It was no great matter for Witherspoon, when called to lecture in moral philosophy and divinity at the College of New Jersey, to exploit, almost to the point of plagiarism, the best texts of his native land, even if they had been written by his onetime bete noir, Hutcheson. ${ }^{30}$ The noteworthy change in America was not that Witherspoon was now cribbing Hutcheson's System of Moral Philosophy (1755) for his lectures, but that Hutcheson's moral philosophy became the engine that drove his activity in society and provided, to some extent, his views in theology. In America, that is, the moral philosophy of Francis Hutcheson was being asked to secure the social ordering which in Scotland had been provided by the traditional hierarchy and the hegemony of the established church. The Common Sense Moral philosophy that had functioned within the casing of Calvinist institutions and thought in the Scottish environment had, when translated to the open American environment, itself become the casing for convictions about theology and social order.

A third major difference between America and Scotland in this period concerns the appropriation of civic humanist theories about politics and social order. The bonds among revivalism, evangelical practice, and democratic republicanism that were so important in America simply did not exist in Scotland. During the reign of the Moderates in the eighteenth century, the 'Popular' party of Witherspoon and John Erskine propounded more democratic conceptions of social order than did William Robertson and his colleagues. But these eighteenth-century evangelicals were 'Popular' only in their resistance to patronage and their support for the ecclesiastical

${ }^{29}$ A substantial biography is V. L. Collins, President Witherspoon (Princeton, Princeton University Press 1925). The best study of the apparent contradictions between Witherspoon the Scot and Witherspoon the American, which finds significant continuity in Witherspoon's consistent attention to wider worlds of revivalism and learning, is $\mathrm{N}$. Landsman, John Witherspoon and the Problems of Provincial Identity in Eighteenth-Century America', in R..B. Sher and J. Smitten (edd.), Scotland and America in the Age of the Enlightenment (Edinburth, University of Edinburgh Press, forthcoming).

${ }^{30}$ For the extent of Witherspoon's borrowing, see J. Scott, 'Introduction', An Annotated Edition of Lectures on Moral Philosophy by John Witherspoon (Newark, University of Delaware Press 1982). 
authority of heritors and elders. ${ }^{31}$ They were always far from egalitarian. During the 1770 s when some of the Scottish lower orders demonstrated against Wilkes and Roman Catholic emancipation, Erskine and his evangelical colleague Charles Nisbet did speak out for the American patriots against the British attempt to subdue the colonies. But the burden of Erskine's widely noticed tract, Shall I Go to War with My American Brethren $(1769,1776)$, betrayed more concern about the advance of Roman Catholicism in the new world than it did about the political rights of the colonists. ${ }^{32}$ And Nisbet, the 'advanced' thinker in Scotland, became greatly disillusioned with the excesses of American liberty following his migration to the states after the War. ${ }^{33}$

Principles of public virtue, freedom from tyranny, and mixed government remained important for Scottish churchmen in the half century after the American Revolution. But these principles continued to support the status quo in politics and, by implication, theology. ${ }^{34}$ The French Revolution and the spectre of Tom Paine especially discouraged political radical-ism and gave a great boost to orthodoxy of every kind. ${ }^{35}$ When in the 1830 s the rising evangelical power in the Kirk established an alliance with the Whig Parliament and its Scottish managers, the Whig ideology was still moderate and pro-government, most unlike the suspicious and anti-hierarchical 'Real

${ }^{31}$ See R. Sher and A. Murdoch, Patronage and Party in the Church of Scotland, 1750-1800', in Church, Politics and Society, 208-11, 215; and R. B. Sher, Church and University in the Scottish Enlightenment: The Moderate Literati of Edinburgh (Princeton, Princeton University Press 1985) 262-76.

${ }^{32}$ D. I. Fagerstrom, 'Scottish Opinion and the American Revolution', William and Mary Quarterly 3rd ser. 11 (1954) 265-6.

${ }^{33}$ See J. H. Smylie, 'Charles Nisbet: Second Thoughts on a Revolutionary Generation', The Pennsylvania Magazine of History and Biography 98 (1974) 189-205.

${ }^{34}$ Sher, Church and University in the Scottish Enlightenment 187-212, 'WhigPresbyterian Conservatism, or "public Virtue"".

${ }^{35} \mathrm{G}$. D. Henderson, 'Religion and Democracy in Scottish History', in The Burning Bush: Studies in Scottish Church History (Edinburgh, Saint Andrew 1957) 1312; T. C. Smout, A History of the Scottish People 1560-1830 (London, Collins 1969) 220; V. Kiernan, 'Evangelicalism and the French Revolution', Past and Present , 1 (1952) 44-56; A. C. Cheyne, The Transforming of the Kirk: Victorian Scotlands Religious Reoolution (Edinburgh, Saint Andrew 1983) 11; and Drummond and Bulloch, Scottish Church 1688-1843 149. 
Whiggery' that loomed so large in America. Across the Atlantic, the democratization of theology came about through the Revolution and the application of Radical Whig ideology to religion. In Scotland, democratic language did reenter the religious sphere in the early decades of the nineteenth century. But it was to be most found among the Congregational and Baptist followers of the Haldanes who functioned at the margins of intellectual influence, or, when in the established church, as a by-product of attempts to defend hereditary religious practices. ${ }^{36}$ Liberty in Christ was every bit as important in Scotland as in America. But once again, the discourse of liberty was contained by the traditions of theology and church instead of containing them.

At the Disruption in 1843, theology in Scotland still belonged to the church and was still self-consciously dependent upon ancient religious traditions. Much had changed from the age of Knox and the later era of the National Covenant, but an indication of how much had not changed is provided by the fact that after nearly one and a half centuries of rule from London, the Scottish Kirk still administered the Poor Law and still ran the nation's schools, in which the Bible remained the central text. ${ }^{37}$ In 1843 the overwhelming majority of Scotland's churchgoing population still adhered to an ideal of national religious comprehensiveness. Both major factions in the established church, along with the tiny minority of Reformed Presbyterians and Old Light Anti-Burghers, still contended for the notion of a nation in covenant with God. That sentiment was probably strongest among evangelicals who became leaders of the Free Church after the Disruption. It is of telling significance that the great goal of Thomas Chalmers, who 'was acclaimed in a manner seldom accorded to any Scot in his own lifetime', was to solve the crisis of urban Scotland by promoting a comprehensive national plan of parish paternalism. ${ }^{38}$ The

\footnotetext{
36 Henderson, 'Religion and Democracy in Scottish History' 132-34.

37 Smout, Scottish People 1560-1830 457; and C. Smout, 'Centre and Periphery in History: With Some Thoughts on Scotland as a Case Study', Journal of Common Market Studies 18 (1980) 264.

${ }^{38}$ Quotation from T. C. Smout, A Century of the Scottish People, 1830-1950 (New Haven, Yale University Press 1986) 181; a full portrayal of that effort can be
} 
point is not whether he failed or succeeded, but that such a goal was prominent at such a time. Taken as an exemplar, the experience of Chalmers shows that Scottish churchmen aspired to a comprehensive control of their own affairs, including their theology, almost unimaginable in America at the same time.

Such structural differences between America and Scotland do not by themselves explain the development of theology in the two regions. They do suggest, however, that in Scotland the story of the development of doctrine is a story primarily within the church. Much more than in America, it was still ecclesiastical history that explained the relative strength of traditional Calvinism in Scotland on the eve of the Disruption.

The relatively undiluted Calvinism of mid-century Scotland, therefore, depended especially on two developments in the internal life of the church. First, throughout the period of Moderate dominance, Scotland's evangelicals retained a large measure of doctrinal Calvinism, which then came to more public expression at their own rise to power in the Kirk. Secondly, in the early decades of the nineteenth century, the religious life of Scotland experienced a significant infusion of more militant Calvinism from covenanters and from the newly evangelized Highlands.

At least until the 1830 s and 1840 s the evangelical tradition in the established church was not known for its doctrinal precision as such. Its leaders tended to be activists who simply took their bearings from the Westminster standards rather than rigorists who worried about jots and tittles of doctrine. Yet John Witherspoon and John Erskine in the eighteenth century and the circle around Thomas Chalmers in the nineteenth nonetheless pursued their practical labors within a framework established by their confession. The sum of the matter is that although the evangelical party may have blurred some of the sharp edges of its doctrinal Calvinism in the century after Cambuslang, its leading figures continued to embrace the main outlines of that system and showed very little tendency to

found in S. J. Brown, Thomas Chalmers and the Godly Commonwealth in Scotland (New York, Oxford University Press 1982). 
modify or repudiate that heritage as many of their evangelical contemporaries were doing at the same time in America. ${ }^{39}$

Theological development in Scotland was also influenced by figures who spoke out forcefully and effectively for a more strenuous Reformed faith. Although the Old Light Anti-Burghers and the Reformed Presbyterians were still no more than a tiny majority in the early nineteenth century, their determined defense of the national covenant in tandem with rigorous Calvinism gave them an unusual public influence among a people still swayed by history and tradition. The nature of that influence is well-illustrated by the biographies of John Knox and Andrew Melville published in 1811 and 1819 by Thomas McCrie, a leader of the Old Light Anti-Burghers. These books were very popular, and they encouraged a broad public to reaffirm Scotland's hereditary Calvinism. ${ }^{40}$

Even more important than the impact of these histories for the continuation of a rigorous Calvinism was the conversion of the Highlands. During the breakup of the clans after The Forty-Five and the disastrous economic and social shocks suffered by the region over the next century, the Christianizing work of the Scottish Society for the Propagation of Christian Knowledge and the indigenous labours of the Highland 'Men'lay elders of the Church-exerted a tremendous impact. The result was that by the early nineteenth century a Presbyterianism both vigorous in its evangelical zeal and rigorous in its Calvinistic profession had come to dominate that area. ${ }^{41}$ For an entire region, even if declining in population, to embrace such a strenuous faith meant a great deal for the renewal of Calvinism precisely at a time when it was fading away in other regions of the North Atlantic world.

${ }^{39}$ See J. Roxborough, 'Chalmers' Theology of Mission', in A. C. Cheyne (ed.), The Practical and the Pious: Essays on Thomas Chalmers (1780-1847) (Edinburgh, Saint Andrew 1985) 174-85.

${ }^{40}$ Drummond and Bulloch, Scottish Church 1688-1843 213; and I. Murray 'Biographical Introduction', Historical Theology by William Cunningham (London, Banner of Truth 1960) vi.

${ }^{41}$ See J. MacInnes, The Evangelical Movement in the Highlands of Scotland, 1688-1800 (Aberdeen, The University Press 1951); Smout, Scottish People 1560 1830 358, 463, 465, 498; Smout, Scottish People 1830-1950 198; Smout, 'Centre and Periphery' 268; and Drummond and Bulloch, Scottish Church 1688-1843 215. 
By the 1830s Scotland was wealthy and rapidly modernizing. It had enjoyed two generations of an Enlightenment that was frequently the envy of educated Europe. By some reckonings this social and intellectual climate should have made Scotland a prime candidate for the decline of Reformed theology and the rise of more human-centred faith. Yet at that very time Calvinism in both doctrinal and practical forms had not been stronger in Scotland for at least a century. Sabbatarianism and a religiously inspired anti-Catholicism were on the rise. 42 The evangelicalism of the Church in the Lowlands and of the SSPCK in the Highlands decisively shaped the public ethos of the nation.

To be sure, the stricter Calvinists by no means had things to themselves. By the 1830s significant challenges had been issued to hereditary formulations of the faith. Within the Kirk, John McLeod Campbell was arguing for a universal atonement and against the penal view of Christ's sacrifice, while his one-time colleague Edward Irving was promoting what would today be called a charismatic message..$^{43}$ In the New Light United Secession church James Morison was reading Charles Finney's Lectures on Revivals of Religion and promoting 'new measures' in evangelism. Like Campbell, he also advocated a universal atonement. ${ }^{44}$ Beyond Presbyterianism, Thomas Erskine of Linlathen was attempting to reconstitute theology on the basis of the love of God instead of the divine decrees of the hereditary confession. ${ }^{45}$

\footnotetext{
${ }^{42}$ Drummond and Bulloch, Scottish Church 1688-1843 214.

${ }^{43}$ On Campbell, see B. A. Gerrish, 'The Protest of Grace: John MacLeod Campbell on the Atonement', in Tradition and the Modern World: Reformed Theology in the Nineteenth Century (Chicago, University of Chicago Press 1978) 71-98; and G. M. Tuttle, So Rich a Soil: John McLeod Campbell on Christian Atonement (Edinburgh, Handsel 1986); and on Irving, A. A. Dallimore, Forerunner of the Charismatic Movement: The Life of Edward Iroing (Chicago, Moody 1983).

${ }^{44}$ See R. Carwardine, Trans-atlantic Revivalism: Popular Evangelicalism in Britain and America, 1790-1865 (Westport, Conn., Greenwood 1978) 98-100; Drummond and Bulloch, Scottish Church 1688-1843 219; and J. Macleod, Scottish Theology in Relation to Church History Since the Reformation (Edinburgh, Banner of Truth 1974, orig. 1943) 242-3.

${ }^{45}$ Drummond and Bulloch, Scottish Church 1688-1843 $194-9$.
} 
The central historical circumstance of the $1830 \mathrm{~s}$, however, was the unqualified rejection of such views by the Scottish denominations. Unlike the situation in America, where 'advanced' thinkers like Lyman Beecher and Albert Barnes survived judicial challenges, and where N. W. Taylor's extensively modified Calvinism came to dominate New England, the Scottish church actively repulsed departures from the Westminster Confession. The established church deposed McLeod Campbell, Irving, and a series of other ministers who shared their views. The United Secession was the Scottish Presbyterian denomination most willing to move with the times, but it deposed Morison. ${ }^{46}$ In the Church of Scotland during the Ten Years' Conflict before 1843 evangelical Calvinism became more prominent among both the antipatronage party and the middle group of evangelicals willing to tolerate the old arrangements. At the Disruption, few doubted that the new Free Church was the central source of religious energy in ecclesiastical Scotland. Theological direction for the young denomination came from the hastily established New College in Edinburgh where younger men like William Cunningham and James Bannerman joined Thomas Chalmers, David Welsh, and John Duncan as unusually forceful exponents of Reformed theology. ${ }^{47}$

To all appearances, the theological contrast to America could not be greater. Post-Calvinist opinions on human ability, the atonement, predestination, and 'new measures' had come to prevail widely in America, with Old School Presbyterians and a remnant of New England Congregationalists keeping alive the objections of a small minority. In Scotland, however, the Calvinistic positions were maintained in the churches with seemingly growing strength, while positions similar to those that defined the mainstream in America were under great fire inside and outside the main Presbyterian denominations. The contrast is striking. Of many ways to explain it, one at least must be that, unlike America, Scottish religious thought remained more completely under the control of the Scottish

46 Ibid. 193-219.

47 Murray, Introduction to Cunningham's Historical Theology xvii; Cheyne, The Transforming of the Kirk 7-8; and Macleod, Scottish Theology 263-4. 
church, and that, also unlike America, the internal life of the church was witnessing an increasing rather than declining infusion of traditional Calvinist thought.

At this point the history is over, and a short sermon begins. The first homiletic lesson concerns the fate of Christian doctrine in a secularized world. In America from 1735 theology was being done in a secularized setting. It takes us beyond the scope of this paper, but the same thing could be said about Scotland after 1843, when modern thought, especially in political economy, combined with the effects of the Disruption to create a much more privatized religion there. ${ }^{48}$ By secularization, I mean here not so much blatant antiChristianity as formal changes in the institutional make-up of society. The intellectual histories of America after 1735 and Scotland after 1843 follow nearly exactly the description offered by David Martin of the transition from ancient religious cultures to modern secular ones:

The key word is differentiation, meaning the splitting off of sectors, so that religion becomes one specific sector not the essence of the whole...Above all the casing of thought ceases to be theological. Philosophy is naturalized and becomes natural philosophy and subdivides yet again into moral philosophy and other branches. Law finds a justification in social necessity rather than divine edict. Morals seek a foundation in rules of reciprocity and a calculus of happiness. The state appeals to the voice of the people rather than the voice of God... Social sciences are gradually severed from divine services. Education and welfare are resettled under the aegis of the state. Eventually even the wholeness of the mind separates itself from the holiness of the soul; priests retain the cure of the soul and social workers or psychiatrists attempt the cure of the mind. ${ }^{49}$

In both America and Scotland ecclesiastical events and intellectual alliances broke down the 'casing' that theology had once provided for all of society.

${ }^{48}$ I am influenced here by C. G. Brown, The Social History of Religion in Scotland since 1730 (London, Methuen 1987) esp. chs. 5, "The Challenge of the Cities, 1780-1890", and 6, "The "Social Question" and the Crisis for Religion, 1890-1929'; and S. Mechie, The Church and Scottish Social Development, 17801870 (London, Oxford University Press 1960).

${ }^{49}$ D. Martin, 'General Tendencies and Historical Filters', in Annual Reoiew of Social Science of Religion 3 (1979) 10. 
The point to be made about such a historical situation for those who are concerned about the integrity of theology is a nice one. It cannot be primarily that secularization, in the sense of the broken casing, is the source of non-Calvinist theologies. Anthropocentric theologies can arise in such secularizing situations, but some theologies emphasizing the rights and powers of humans before God are a proper Christian corrective to others that downplay the importance of spiritual activism or the comprehensiveness of divine grace. Nor is the point necessarily that influences from the languages of politics, economics, or social organization always exert a detrimental effect on theology. In fact, insights from the world at large may through general revelation actually assist in the development of doctrine. So it was that in Tudor-Stuart England, evolving conceptions of social and commercial order lent a hand to the development of English covenantal theology. Several centuries later, the expansion of British imperial and commercial interests played a part in the development of English-speaking missionary theology..$^{50}$ Alternatively, those within the church may, because of finitude or the lingering effects of sin, misunderstand or misapply special revelation in the formation of theology.

The precise point to be made is rather that the church must counter secularization of the sort Martin describes-and counter it structurally, intellectually, institutionally, existentially as much as on the level of specific questions-if it is to chart its own theological course. Alliances, crossfertilizations, and confluences of thought between church and world may contribute to the integrity of theology and its independence, but only if religious thinkers appropriate the wisdom of the world with deliberate self-consciousness. Where, on the other hand, the church appropriates that wisdom unselfconsciously, without explicit discriminations, it runs a risk of losing control of its own intellectual destiny.

Churches maintain the independence of their theologies in different ways. Anabaptists have sought that goal by

${ }^{50}$ See D. Zaret, The Heavenly Contract: Ideology and Organization in PreRevolutionary Puritanism (Chicago, University of Chicago Press 1985); and K. S. Latourette, A History of the Expansion of Christianity IV The Great Century: Europe and the United States (Grand Rapids, Zondervan 1970, orig. 1941) 66. 
systematic separation from the world, Roman Catholics by exalted claims for the hierarchy, and Lutherans by affinity for a theory of Two Kingdoms. The tendency of Reformed and evangelical Protestants has been to seek theological independence through intellectual self-discipline precisely while working energetically at transforming the surrounding world for Christ. ${ }^{51}$ The histories of both America and Scotland reveal the great potential effect of such Reformed and evangelical strategies. They also show how easy it can be, because of the deep immersion in society required for such an effort, for minds to be transformed by the world they are seeking to transform.

The second homily grows from the first. It concerns the way that such a study of doctrinal development in history contributes to the development of doctrine itself. We have seen in the histories of Scotland and America how the very embodiment of the church in its world plays a role in theological formation, how the historical circumstances of church life exert an influence on the church's thought. To take such conclusions seriously can lead in at least two directions.

On the one hand, it might seem to support arguments for historical relativism, either an extreme historicism that pictures all thought, including theology, as products of the thinkers' cultural or material conditions, or a less extreme process view in which God, and therefore theology, changes over time because God is immanent without remainder in the evolving world. These, however, are the wrong conclusions to be drawn from such a historical exercise. ${ }^{52}$

The proper conclusion, and the conclusion contributing to a positive understanding of the development of doctrine, lies in another direction entirely. This conclusion is that to see how political, philosophical, social, and economic circumstances play a shaping role in the history of doctrine; a perception especially pertinent to the eighteenth and nineteenth centuries which makes more vivid, rather than less, the Christian

${ }^{51}$ H. Richard Niebuhr, Christ and Culture (New York, Harper and Row 1951) remains a helpful typology for describing these tendencies.

52 For a somewhat fuller discussion of why a recognition that history shapes thought need not lead to historical relativism, see M. A. Noll, 'Scientific History in America: A Centennial Observation from a Christian Point of View',Fides et Historia 14 (1981) 28-31. 
doctrines of revelation, providence, and Incarnation. When we conclude that all statements about God are conditioned by the contexts in which they are uttered, we may be verging toward historical relativism. We may also be verging toward a deeper understanding of biblical theology. For what the Bible shows us is a diety, absolute in his perfections, who nevertheless has spoken-indeed, has become-the Word in the contexts of history. Furthermore, what the Christian doctrines of revelation and Incarnation imply for God's embodiment in human history at particular times and places, the doctrine of providence affirms for the divine shaping of human history at all times and in all places.

The Christian doctrines of revelation, Incarnation, and providence concern God's acting in the world. Chalcedonian Christology reaffirms the thoroughness with which God entered the world he made. The final rationale for seeking to trace the development of doctrine in the circumstances surrounding the church as well as through the church's internal life is that such a procedure mimics the way that God has made himself known.

To put matters a different way, the development of doctrine that we observe in Scotland and America during the eighteenth and nineteenth centuries was partaking to some degree of the cultural circumstances of Scotland and America in the eighteenth and nineteenth centuries. Participants at the time sensed this cultural shaping only dimly, while we are able to see it somewhat more clearly. When considering the clarification of Christian doctrine over time, we, therefore, are the primary beneficiaries, for we are given to see with slightly more clarity-precisely because of that history of doctrinal development-the significance of revelation, Incarnation, and providence. Our increased understanding of how history shapes doctrine may seem at first disconcerting, for it means our norms for judging doctrines are themselves historical. It means also that even the Bible functions not as a disembodied abstraction of the truth, but as itself a history of the speech and actions of redemption. We seem, in other words, to be exchanging the stability of everlasting dogma for the flux of historical dialectic. 
But the dialectic of Christian history is a dialectic with a difference. In the end, there need be no recoiling from the observation that history shapes doctrine, for the heart of the doctrine revealed in history with ever more penetrating power, ever more enthralling joy, is that God shapes history through history, that the Word by whom all things were made has become flesh and dwells among us.

At the Protestant Colloquy of Marburg in 1529, an exasperated Oecolampadius, after vigorous debate with Luther on key New Testament texts concerning the Lord's Supper, burst out to admonish his opponent: 'Don't cling so fast to Christ's humanity and flesh! Raise your thoughts to Christ's divinity!' But Luther replied, 'I know God only as he became human, so I shall have him in no other way. ${ }^{53}$ So do we know Christian doctrine only as it becomes historical, and so may we, because of the Incarnate Word, rejoice to have it in no other way.

${ }^{53}$ D. J. Ziegler (ed.) Great Debates of the Reformation (New York, Random House 1969) 94. 